\title{
Assessing Miles and Snow Typology through the Lens of Managerial Discretion: How National-Level Discretion Impact Firms Strategic Orientation
}

\author{
Moustafa Salman Haj Youssef ${ }^{1, *}$ \& Ioannis P. Christodoulou ${ }^{1,2}$ \\ ${ }^{1}$ Westminster Business School, University of Westminster, 35 Marylebone Road, NW1 5LS, London, United \\ Kingdom. \\ *Correspondence: Westminster Business School, University of Westminster, 35 Marylebone Road, NW1 5LS, \\ London, United Kingdom. E-mail: m.hajyoussef@westminster.ac.uk
}

Received: January 10, 2017

Accepted: January 14, 2017 Online Published: January 25, 2017

doi:10.5430/mos.v4n1p67

URL: http://dx.doi.org/10.5430/mos.v4n1p67

\begin{abstract}
Studies on the implications of managerial discretion have mainly focused on the firm, executive or industry level attributes. Little work has tackled the national-level aspect of this construct and its potential implication on firm strategies. We seek to theoretically establish an association between the construct of managerial discretion and firm strategic orientation from a national-level. Our theoretical analysis strongly suggests that the degree of managerial discretion available to executives in each country could have a strong influence on companies' competitive strategy. We contribute to the strategic management field and the discretion literature by uncovering new national-level implications.
\end{abstract}

Keywords: strategic orientation; miles and snow typology; managerial discretion; national-level; competitive strategy

\section{Introduction}

Managerial discretion, a bridge between two polar views (Hambrick \& Finkelstein, 1987), has almost achieved its pearl jubilee of resolving the debate between two schools of thoughts. On the one hand, population ecology (Hannan \& Freeman, 1977), resource dependence (Pfeffer \& Salancik, 1978), and neo-institutionalism (DiMaggio \& Powell, 1983) postulate evidence asserting that executives are constrained in the way they take strategic choices due to isomorphic, environmental, inertial and relentless forces. On the other hand, work on executive effects (e.g. Hambrick \& Quigley, 2014), and upper echelons (Hambrick \& Mason, 1984) provide contrasting outputs emphasizing the fundamental importance of top managers in shaping and influencing organizations' outcomes. To bridge these opposing school of thoughts, Hambrick and Finkelstein (1987) introduced the concept of managerial discretion, whereby they argued that exectuives are able to influence organizational outcomes as long as the internal or external environment allows them to do so. Despite triggering a new stream of research, managerial discretion remains vague in terms of its consequences or implications on firms' outcomes particularly strategy. The former, which represent the most frequently considered outcome of discretion (Wangrow et al, 2015), has been extensively used in various discretion studies in which empirical findings show that high discretion lead to augmented executives (particularly CEO) effect on firm performance (e.g. Adams et al, 2005; Crossland \& Hambrick, 2007, 2011; Wasserman et al, 2010; Hambrick \& Quigley, 2014). Rajagopalan and Finkelstein (1992) triggered a distinct research brook that adopted executive compensation as an implication of discretion. Few other studies examined substitute consequences, for instance corporate governance (Singh \& Harianto, 1989); industry attentional patterns (Abrahamson \& Hambrick, 1997), CEO individualities (Datta \& Rajagopalan, 1998), efficiency of organizational strategies (Peteraf \& Reed, 2007); debt usage (Keegan \& Kabanoff, 2008) and most recently CEO dismissal sensitivity (Crossland \& Chen, 2013). Although these attempts have enhanced our understanding of the managerial discretion effects, this model lacks a dearth of research into a core implication, firm competitive strategy.

So far, these are the only studied outcomes (CEO accountability for poor firm performance and CEO effect on firm performance) of managerial discretion at the national level. The national-level framework provides a great 
opportunity for researchers to discover new insights and develop the theory further. Crossland and Hambrick (2011) indirectly and briefly proposed that the association between managerial discretion on the national-level and firm competitive strategy may exist. However, they haven't developed this idea further neither they did empirically test it. Thus, the theoretical reasoning behind such proposition is still vague. Accordingly, our aim is to uncover and theoretically establish such association. Our paper is built upon Crossland and Hambrick (2011) national-level discretion by arguing that discretion at this aggregate level play a crucial role in determining organizational strategic orientation.

\section{Managerial Discretion Review and Research Gap}

Despite being in existence for more than three decades, managerial discretion paradigm lacks fundamental improvements. It has emerged as a pivotal concept linking two opposed perspectives. On the one hand, deterministic perspectives including population ecology (Hannan \& Freeman, 1977), resource dependence (Pfeffer \& Salancik, 1978), and neo-institutionalism (DiMaggio \& Powell, 1983) argue that significant unavoidable forces such as: isomorphic pressures, environmental challenges, internal inertia, etc. severely restrain managers behaviour. This research stream attribute little or even no effects for executives on firms' fate. On the other hand, scholars who possess interest in strategy argued that executives' actions considerably influence organizations' outcomes (Child, 1997; Hambrick \& Mason, 1984).

Hence, managerial discretion, which relates to the latitude of strategic action provided to top managers (Hambrick \& Finkelstein, 1987), resolves this debate by moving the discussion from whether to when executives matter. Since then, a new research stream has developed investigating the various precursors of discretion. These vary from micro (individual) to macro (national) levels. Executive individualities including locus of control, commitment to the status quo, age, tenure, education, risk taking behaviour, etc. were proxies of discretion (e.g. Miller et al, 1982; Roth, 1992; Carpenter \& Golden, 1997; McClelland et al, 2010). Moving up the ladder, another sub-group of researchers assessed organizational factors such as: organization structure, R\&D intensity, sales, culture size, slack, etc., whereby they argued that such organizational variables may well define the laltitude of executive of action (e.g. Werner \& Tosi, 1995; Finkelstein \& Boyd, 1998; Key, 2002; Quigley \& Hambrick, 2012; Kim, 2013). At a more macro level, task environment or industry antecedents represent the bulk of discretion studies. In here, scholars have examined regulatory conditions, market growth, product differentiability, capital intensity, demand stability (e.g. Haleblian \& Finkelstein, 1993; Magnan \& St-Onge, 1997; Datta \& Rajagopalan, 1998; Peteraf \& Reed, 2007; Keegan \& Kabanoff, 2008; Finkelstein, 2009; Hambrick \& Quigley, 2014) along with other industry factors as influencers of the discretion level available in certain industries. Up until recently, Crossland and Hambrick (2007, 2011) gave birth to a fourth dimension of discretion, arguing that national institutions (formal and informal) influence the degree of discretion available to executives. The national level represents another antecedent of discretion; however, it is still in its early phases.

Moving away from antecedents, another research stream have analyzed the consequences of managerial discretion. The discretion concept mainly argues that a CEO effect on firm performance is greater if he/she possesses higher latitude of actions (Wangrow et al, 2015). Adams et al (2005) found that discretion emerging from a CEO power base allows greater effect on firm performance. Similarly, Crossland and Hambrick (2007) provided strong support for the relationship between discretion and CEO effect on firm performance, where they showed that CEOs in high discretion countries (e.g. US) possess higher effect on performance compared to others in low discretion countries (e.g. Japan). Also, evidence from Hambrick and Quigley (2014) who formulated a new method to evaluate CEO effects on performance, illustrate that CEOs operating in high discretion industries have greater effect on their firms' performance as opposed to their counterparts in low discretion industries. Thus, regardless of its antecedent (either individual, industry or national level) discretion results in higher CEO effect on performance. From an agency perspective, scholars argued that greater discretion leads to augmented CEO compensation (e.g. Rajagopalan \& Finkelstein, 1992, Boyd \& Salamin, 2001; Finkelstein, 2009). Though, this phenomenon is stouter for CEOs with extraordinary performance (Finkelstein \& Boyd, 1998). Hence, alternative commonly considered result of discretion is CEO compensation.

Additionally, discretion through individual characteristic or other internal/external proxies was seen to sway: firms' risk taking, innovative and change behaviour (Miller et al, 1982; Makhija \& Stewart, 2002; Quigley \& Hambrick, 2012), and CEOs commitment to the status quo (McClelland et al, 2010). Few others tested the impact of discretion on other elements such as: industry attentional modes (Abrahamson \& Hambrick, 1997), debt usage (Keegan \& Kabanoff, 2008), CEO characteristics (incl. age, tenure, educational level and throughput background) (Datta \& 
Rajagopalan, 1998), efficient firms' strategies (Pfeffer \& Reed, 2007) and industry exports (Sahaym et al, 2012). Despite these attempts, significant firms' outcomes remain ambiguous and most likely to be affected by discretion. Out of these outcomes is the strategic orientation. Following this logic, we are applying Miles and Snow (1978) strategic typology in a reverse manner. In other words, we are not theoretically linking the impact of strategic orientation on discretion, which has been previously established; instead we are examining the effect of discretion at the national level on firms' strategic orientation.

Miles and Snow (1978) developed a typology arguying that firms'compeititve strategy can be categorized as follows: Prospector, Defender, Analyzer and Reactor. Each has its own strategic orientation, which will be discussed in more details in the next section. It is important to note that the 'Reactor' strategy is not included in our theoretical analysis because; it is a form of strategic failure (Miles et al, 1978) and hasn't been discovered in previous studies (e.g. Rajagopalan, 1997). The core discussion relates to 'Prospector', 'Defender' and 'Analyser' type of competitive strategy. Earlier studies on Miles and Snow typology have overlooked the consequences of the strategic orientation, particularly from the discretion lens. Authors like Rajagopalan and Finkelstein (1992), Rajagopalan (1997) and Boyd and Salamin (2001) all took strategic typology as proxies of discretion. Stemming one-way relationship between strategies and discretion, but none has tried to investigate the reverse liaison. Yes, we agree that strategies reflect executives' demographic and cognitive attributes (Hambrick \& Mason, 1984), but to assure the presence of such reflection, managers need to possess discretion. Departing from this logic, our main argument is to assert that firms' business-level strategies (how to compete in a business) become the result and not the cause.

\section{Miles and Snow Typology}

Business-level strategy represents a key premise in the normative literature (e.g. Porter, 1990) in which strategies are an adaptation mechanism between the business and its environment (Hambrick, 1983). Whereas, others defined strategies descriptively. Miles and Snow (1978) stood to such logic by viewing strategy as immutable (Hambrick, 1983) in the sense that a business is constrained by the strategy adopted in response to its environment. In other words, with time the firm progresses habitual mechanisms to respond to environmental jolts. Accordingly, Miles and Snow (1978) developed their strategic typology by postulating the existence of four generic strategies: prospectors, defenders, analyzers and reactors.

Prospectors and defenders represent the two extremes of this typology in which the latter reflects firms having an engineering orientation that focus almost solely on specific, stable and niche market/product domain. Whereas, the former, prospector, have a technology orientation concentrating on continuous market/product innovation. Analyzers play a balancing role by combining characteristics from both strategic type extremes (Prospectors and Defenders) and act like defenders in stable domain but follow a prospector in a more volatile realm. Lastly, reactors lack clear strategic orientation due to their short-term emphasis (DeSarbo et al, 2005).

As previously mentioned, earlier studies have used firms' strategic orientation as proxies to assess discretion. Rajagopalan and Finkelstein (1992) were first to employ strategic orientation within the discretion framework. By testing their assumptions on a sample of 50 firms within the electric utility industry, Rajagopalan and Finkelstein (1992) found a positive relationship between strategic orientation particularly prospector strategy and executives' compensation. In other words, due to the high discretionary strategic orientation of prospectors, executives leading such firms tend to have greater, cash and an outcome-based compensation plan. Firms' strategic orientation was adopted as an antecedent of discretion not as an outcome. Likewise, Rajagopalan (1997) used strategic orientation as a predictor of discretion by assessing its impact on executives' compensation plans. He emphasized the importance of fit between compensation plan and firms' strategies, and found that firms with prospector strategies implement more stock-based incentive procedures and evaluate performance in accordance to market measures (Rajagopalan, 1997). By deviating from the commonly used context in prior research (US), Boyd and Salamin (2001) gauged the impact of strategic orientation on pay systems in a set of Swiss financial firms. Findings show consistency with previous research that strategic orientation plays a role in defining pay systems. Overall, studies so far have identified strategic orientation as a predictor of discretion. Put it simply, firms' generic strategies define the level of discretion provided to its top managers, for instance prospectors provide greater discretion and defender strategies constraint executive behaviour thus offer low discretion (Miles \& Snow, 1978; Rajagopalan, 1997). However, a reversible relationship is true as well. In contexts with high discretion level due to greater product differentiability, dynamic status, etc. allow managers to foresee wider array of strategic actions. When executives possess various options, from which to implement, then allowing them to explore innovative actions that result in implementing a prospector strategy. 
Hambrick and Finkelstein (1987) argue that for executives to enjoy high discretion levels, first they must be aware of a wide variety of strategic actions to choose from that falls within the zone of acceptance of important stakeholders. Second, discretion occurs to the extent to which those stakeholders lack the power to object or sanction executives' actions (Crossland \& Hambrick, 2011). Low discretion countries constraints executives from taking risky and unpredictable actions, which will indeed be reflected in their firm strategic orientation. On the other hand, high discretion contexts would enable executives to foresee a broader range of actions and to implement change and innovate, which will also be reflected in their firm strategic orientation. Therefore, the firm strategic orientation should be in-line with the discretion levels available for executives in each country. It is almost impossible for an executive to foresee risky strategies if the external environment does not allow or tolerate such behavior.

\subsection{Prospector Strategy}

Prospectors are firms that endeavor to pioneer in market and product development, they primarily compete based on exploiting market opportunities and being the first movers to introduce or change a product line. This type of firms strives to continually explore new market opportunities by regularly experimenting responses to evolving environmental drifts. Firms implementing this strategic type have hunger to innovation; prosper by seeking risky behaviour, embracing new technologies, and maintaining external concentration. Prospectors are often seen as creators of change and uncertainty, but lack complete efficiency in operations. Due to their emphasis on innovation, prospectors are required to possess significant competences in their activities particularly research and development (R\&D) (Hambrick, 1983; Shortell \& Zajac, 1990) and IT abilities to expedite internal communication and functional integration which are crucial for new development (Griffin \& Hauser, 1996; Bharadwaj et al, 1999). Essentially, prospectors have the most sophisticated mechanisms (Miles \& Snow, 1978) because they heavily rely on new product development as the main source of competitive advantage (Robinson et al, 1992). Firms following such strategic orientation have aggressive innovative strategies that are not easily programmable, which generates uncertainty making unchanging policies and behvaior unlikely. These firms flourish in dynamic and volatile environments (Walker et al, 2003). If countries do not provide such atmosphere to executives, then it would be difficult to foresee such strategic orientation. Countries that tend to avoid uncertainty provide executives with low degree of managerial discretion. In this case and due to the limited array of available acceptable actions, they would not be able to foresee any strategic change or aggressive innovative strategies, therefore executives will tend not to foresee the prospector type of strategic orientation.

Furthermore, prospectors are naturally riskier and seek risky actions which is indeed not appropriate and compatible with an environment that do not provide enough leeway to executives. The institutional environment that is characterized by low discretion, would not allow executives to foresee risky strategies simply due to the unpredictability and ambiguity associated with such actions. Hence, prospectors cannot survive in a low discretion context. Accordingly, by controlling for executives individualities we propose that:

Proposition 1: Firms in high discretion countries tend to follow Prospector strategy rather than Defender or Analyzer.

\subsection{Defender Strategy}

Defenders on the other hand are organizations that offer a stable set of products with no or little engagement in market/product development. They accomplish this by securing and protecting market niches, maintaining internal focus along with competing primarily based on efficiency (cost), price, service delivery, quality, etc. (Hambrick, 1983), thus offering limited products or services compared to other competitors. However, the drawbacks of defenders are seen from their inability to adapt to environmental changes because they have an inward orientation by which they ignore other product/market domains to recognize new opportunities (McDaniel \& Kolari, 1987; Shortell \& Zajac, 1990). As opposed to prospectors, defenders do not focus on strengthening R\&D activities instead they tend to possess high levels of market linking, marketing, production capabilities (Conant et al, 1990; Walker et al, 2003) and focus extensively on process improvements, resource efficiency and cost-cutting (DeSarbo et al, 2005). Such firms mainly strive in stable domains and unchanging environments, which provide little options for executives (low discretion) and all actions should be in-line with the stability of the external environment. In such environment, firms are supposed to have predefined actions and operate in a way that focus on efficiency of operations and possess internal orientation, thus, they are expected to foresee a defender strategic orientation. Also, environment that provide low discretion constrain executives' actions and as such executives are expected to continue policies and strategies of the past and are not permitted to deviate from the status quo, which ultimately lead to a defender orientation. Therefore, by controlling for executives individualities we propose that:

Proposition 2: Firms in low discretion countries tend to follow Defender strategy rather than Prospector or 


\section{Analyzer.}

\subsection{Analyzer Strategy}

Prospectors and defenders epitomize the two extremes of a business-level strategy. As a mid-point, 'analyzers' are firms possessing an intermediate type with unique combination of both prospectors' and defenders' characteristics. They tend to be second movers after prospectors in the market/product development; make slower and fewer changes to their products than prospectors but at the same time are less devoted to efficiency and stability than defenders. Analyzers operate selectively, in other words, they imitate and follow prospectors in adopting new products and exploiting market opportunities but just for the ones that have demonstrated successful return. Thus, analyzers adopt a 'second-but-better' strategy (DeSarbo et al, 2005). This strategy is the most challenging to pursue deeming into consideration the balance that should be upheld between innovation (risk taking behaviour) and efficiency in operations (Miles et al, 1978). As it is the mid-point between two extremes (prospector and defender), analyzers are expected to gauge in environments that provide moderate levels of managerial discretion. Environments with moderate levels of discretion are acceptable for specific range of actions and are tolerable for some strategic change. Seeking continuous change and risky strategies like the prospector would be unacceptable but at the same time staying stable as defenders would be deemed as unacceptable as well. So, there must be a balance between the external and internal orientation, which mainly characterizes firms with analyzer competitive strategy. Also, as mentioned earlier, analyzers tend to follow the first movers in their action, they do that to assess the external reaction on the first movers' strategies, if deemed acceptable, then analyzers would follow. As such, by controlling for executives individualities we propose that:

Proposition 3: Firms in moderate discretion countries tend to follow Analyzer strategy rather than Prospector or Defender.

\section{Conclusion and Implication}

Crossland and Hambrick (2011: 815) state that: "National-level managerial discretion might influence a company's competitive strategy". However, they did not explain or theoretically establish the link between managerial discretion and firm competitive strategy. In this paper, we attempt to theoretically build on Crossland and Hambrick (2011) suggestion and establish the association between these two construct and use firm competitive strategy as an outcome of managerial discretion. Despite, earlier research (Rajagopalan, 1997; Rajagopalan \& Finkelstein, 1992) that empirically tested the effect of strategic orientation based on Miles and Snow typology on managerial discretion at the organizational-level, no previous work has considered expanding this level of analysis to a macro-level (country) and no work has considered the opposite relationship by using the firm competitive strategy as an outcome of managerial discretion. We, at least from a theoretical perspective, found the ground of such relationship and expanded the level of analysis to the national context. Therefore, our paper opens an interesting and a new line of enquiry, which relates to the national-level implications of managerial discretion. We strongly encourage future research to consider and try to empirically test our proposed relationships as it helps to broaden the national-level perspective on managerial discretion and would lead to important implications.

\section{References}

Abrahamson, E., \& Hambrick, D. C. (1997). Attentional homogeneity in industries: The effect of discretion. Journal of Organizational Behavior, 18, 513-532. http://doi.org/10.1002/(SICI)1099-1379(199711)18:1+<513: AID-JOB905>3.0.CO;2-8

Adams, R., Almeida, H., \& Ferreira, D. (2005). Powerful CEOs and their impact on corporate performance. Review of Financial Studies, 18, 1403-1432. http://doi.org/10.1093/rfs/hhi030.

Bharadwaj, A. S., Bharadwaj, G. S., \& Konsynski, B. R. (1999). Information technology effects on firm performance as measured by Tobin’s q. Management Science, 45(6), 1008-1024. http://dx.doi.org/10.1287/mnsc.45.7.1008

Carpenter, M. A., \& Golden, B. R. (1997). Perceived managerial discretion: A study of cause and effect. Strategic Management Journal, 18, 187-206. http://dx.doi.org/10.1002/(SICI)1097-0266(199703)18:3<187: AID-SMJ861>3.0.CO;2-U.

Child, J. (1997). Strategic choice in the analysis of action, structure, organizations and environment: Retrospect and prospect. Organization Studies, 18, 43-76. http://doi.org/10.1177/017084069701800104

Conant J., Mokwa M., \& Varadarajan PR. (1990). Strategic types, distinctive marketing competencies, and 
organizational performance: a multiple measures-based study. Strategic Management Journal, 11(5), 365-383. http://dx.doi.org/10.1002/smj.4250110504.

Crossland, C., \& Chen, G. (2013). Executive accountability around the world: Sources of cross-national variation in firm performance-CEO dismissal sensitivity. Strategic Organization, 11, 78-109. http://doi.org/10.1177/1476127012460946

Crossland, C., \& Hambrick, D. C. (2007). How national systems differ in their constraints on corporate executives: A study of CEO effects in three countries. Strategic Management Journal, 28, 767-789. http://dx.doi.org/10.1002/smj.610.

Crossland, C., \& Hambrick, D. C. (2011). Differences in managerial discretion across countries: How nation-level institutions affect the degree to which CEOs matter. Strategic Management Journal, 32, 797-819. http://dx.doi.org/10.1002/smj.913.

Datta, D. K., \& Rajagopalan, N. (1998). Industry structure and CEO characteristics: An empirical study of succession events. Strategic Management Journal, $19, \quad 833-852$. http://dx.doi.org/10.1002/(SICI)1097-0266(199809)19:9<833:AID-SMJ971>3.0.CO;2-V.

DeSarbo, W. S., Benedetto, C. A. D., Song, M., \& Sinha, I. (2005). Revisiting the Miles and Snow strategic framework: Uncovering interrelationships between strategic types, capabilities, environmental uncertainty, and firm performance. Strategic Management Journal, 26, 47-74. http://dx.doi.org/10.1002/smj.431.

DiMaggio P., \& Powell, W. (1983). The iron cage revisited: institutional isomorphism and collective rationality in organizational fields. American Sociological Review, 48, 147-160. http://www.jstor.org/stable/2095101.

Finkelstein, S. (2009). Why is industry related to CEO compensation? A managerial discretion explanation. Open Ethics Journal, 3, 42-56. http://dx.doi.org/10.2174/1874761200903010042.

Finkelstein, S., \& Boyd, B. K. (1998). How much does the CEO matter? The role of managerial discretion in the setting of CEO compensation. Academy of Management Journal, 41, 179-199. Http://doi.org/10.2307/257101.

Griffin, A., \& Hauser, J.R. (1996). Integrating R\&D and marketing: A review and analysis of the literature. Journal of Product Innovation Management, 13(3), 191-215. http://dx.doi.org/10.1016/0737-6782(96)00025-2.

Haleblian, J., \& Finkelstein, S. (1993). Top management team size, CEO dominance, and firm performance: The moderating roles of environmental turbulence and discretion. Academy of Management Journal, 36, 844-863. http://dx.doi.org/10.2307/256761.

Hambrick, D. C., \& Mason, A. P. (1984). Upper Echelons: The organization as a Reflection of its top Managers. The Academy of Management Review, 9(2), 193-206. http://dx.doi.org/10.5465/AMR.1984.4277628.

Hambrick, D. C. (1983). Some tests of the effectiveness and functional attributes of Miles and Snow's strategic types. Academy of Management Journal, 26(1), 5-26. http://dx.doi.org/10.2307/256132.

Hambrick, D. C., \& Finkelstein, S. (1987). Managerial discretion: A bridge between polar views of organizational outcomes. Research in Organizational Behavior, 9, 369-406.

Hambrick, D. C., \& Quigley, T. J. (2014). Toward more accurate contextualization of the CEO effect on firm performance. Strategic Management Journal, 35, 473-491. http://dx.doi.org/10.1002/smj.2108

Hannan, M. T., \& Freeman, J. (1977). The population ecology of organizations. American Journal of Sociology, 82, 929-964.

Keegan, J., \& Kabanoff, B. (2008). Indirect industry- and sub-industry-level managerial discretion measurement. Organizational Research Methods, 11, 682-694. https://doi.org/10.1177/1094428107308897.

Key, S. (2002). Perceived managerial discretion: An analysis of individual ethical intentions. Journal of Managerial Issues, 14, 218-233.

Kim, E. H. (2013). Deregulation and differentiation: Incumbent investment in green technologies. Strategic Management Journal, 34, 1162-1185. http://dx.doi.org/10.1002/smj.2067

Magnan, M. L., \& St. Onge, S. (1997). Bank performance and executive compensation: A managerial discretion

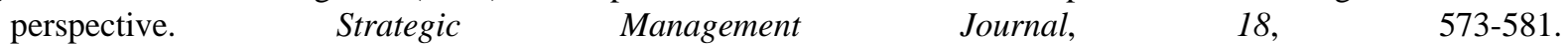
http://dx.doi.org/10.1002/(SICI)1097-0266(199708)18:7<573:AID-SMJ900>3.0.CO;2-K

Makhija, M., \& Stewart, A. (2002). The effect of national context on perceptions of risk: A comparison of planned 
versus free-market managers. Journal of International Business Studies, 33, 737-756. http://www.jstor.org/stable/3069592.

McClelland, P. L., Liang, X., \& Barker, V. L. (2010). CEO commitment to the status quo: Replication and extension using content analysis. Journal of Management, 36, 1251-1277. https://doi.org/10.1177/0149206309345019

McDaniel, S. W., \& Kolari, J. W. (1987). Marketing Strategy Implications of the Miles and Snow Strategic Typology. Journal of Marketing, 51, 19-30. http://doi.org/10.2307/1251245

Miles, R. E., \& Snow, C. C. (1978). Organizational Strategy, Structure, and Process. McGraw-Hill: New York.

Miller, D. T., Kets De Vries, M. F. R., \& Toulouse, J.-M. (1982). Top executive locus of control and its relationship to strategy-making, structure, and environment. Academy of Management Journal, 25, 237-253. http://doi.org/10.2307/255988

Peteraf, M., \& Reed, R. (2007). Managerial discretion and internal alignment under regulatory constraints and change. Strategic Management Journal, 28, 1089-1112. http://dx.doi.org/10.1002/smj.628

Pfeffer, J., \& Salancik, G. R. (1978). The external control of organizations: A resource dependence perspective. New York: Harper and Row.

Porter, M. E. (1990). The Competitive Advantage of Nations. Macmillan, London.

Quigley, T. J., \& Hambrick, D. C. (2012). When the former CEO stays on as board chair: Effects on successor discretion, strategic change, and performance. Strategic Management Journal, 33, 834-859. http://dx.doi.org/10.1002/smj.1945

Rajagopalan, N. (1997). Strategic orientations, incentive plan adoptions, and firm performance: Evidence from electric utility firms. Strategic Management Journal, 18, 761-785. http://dx.doi.org/10.1002/(SICI)1097-0266(199711)18:10<761::AID-SMJ906>3.0.CO;2-2

Rajagopalan, N., \& Finkelstein, S. (1992). Effects of strategic orientation and environmental change on senior management reward systems. Strategic Management Journal, 31(S1), 127-141. http://dx.doi.org/10.1002/smj.4250131010

Robinson W., Fornell C., \& Sullivan M. (1992). Are market pioneers intrinsically stronger than later entrants? Strategic Management Journal, 13, 609-624. http://dx.doi.org/10.1002/smj.4250130804.

Roth, K. (1992). Implementing international strategy at the business unit level: The role of managerial $\begin{array}{lllll}\text { decision-making characteristics. Journal of } & \text { Management, } & 18, & \text { 769-789. }\end{array}$ https://doi.org/10.1177/014920639201800410

Sahaym, A., Treviño, L. J., \& Steensma, H. K. (2012). The influence of managerial discretion, innovation and uncertainty on export intensity: A real options perspective. International Business Review, 21, 1131-1147. http://dx.doi.org/10.1016/j.ibusrev.2012.01.003

Shortell S., \& Zajac E. (1990). Perceptual and archival measures of Miles and Snow's strategy types: a comprehensive assessment of reliability and validity. Academy of Management Journal, 33(4), 817-832. http://dx.doi.org/10.2307/256292

Singh, H., \& Harianto, F. (1989). Management-board relationships, takeover risk, and the adoption of golden parachutes. Academy of Management Journal, 32, 7-24. http://dx.doi.org/10.2307/256417

Walker O., Boyd H., \& Larréché J-C. (2003). Marketing strategy: Planning and implementation (4th ed.). Homewood, IL: Irwin/McGraw-Hill.

Wangrow, B. D., Schepker, J. D., \& Barker III, L. V. (2015). Managerial Discretion: An Empirical Review and Focus on Future Research Directions. Journal of Management, 41, 99-135. https://doi.org/10.1177/0149206314554214

Wasserman, N., Anand, B., \& Nohria, N. (2010). When does leadership matter? A contingent opportunity view of CEO leadership. In N. Nohria and R. Khurana (Eds). Handbook of leadership theory and practice. Boston, MA: Harvard Business Press, 1-63.

Werner, S., \& Tosi, H. L. (1995). Other people's money: The effects of ownership on compensation strategy and managerial pay. Academy of Management Journal, 38, 1672-1691. http://doi.org/10.2307/256849 